\title{
Integrating Mathematics and Science Teaching in the Context of Education for Sustainable Development: Design and Pilot Implementation of a Teaching-Learning Sequence about Air Quality with Pre-Service Primary Teachers
}

\author{
Arantza Rico *(D), Elena Agirre-Basurko ${ }^{+}\left(\mathbb{D}\right.$, Aritz Ruiz-González ${ }^{+}(\mathbb{D}$, Igone Palacios-Agundez $(\mathbb{D})$ and \\ Daniel Zuazagoitia
}

check for updates

Citation: Rico, A.; Agirre-Basurko, E.; Ruiz-González, A.;

Palacios-Agundez, I.; Zuazagoitia, D. Integrating Mathematics and Science Teaching in the Context of Education for Sustainable Development: Design and Pilot Implementation of a Teaching-Learning Sequence about Air Quality with Pre-Service Primary Teachers. Sustainability 2021, 13, 4500. https://doi.org/10.3390/su13084500

Academic Editors: Fermin

Sanchez-Carracedo, Jordi Segalàs Coral and Gemma Tejedor

Received: 24 February 2021

Accepted: 13 April 2021

Published: 18 April 2021

Publisher's Note: MDPI stays neutra with regard to jurisdictional claims in published maps and institutional affiliations.

Copyright: (c) 2021 by the authors. Licensee MDPI, Basel, Switzerland. This article is an open access article distributed under the terms and conditions of the Creative Commons Attribution (CC BY) license (https:/ / creativecommons.org/licenses/by/ $4.0 /)$.
Department of Mathematics, Experimental and Social Sciences Education, University of the Basque Country UPV /EHU, 01006 Vitoria-Gasteiz, Spain; elena.agirre@ehu.eus (E.A.-B.); aritz.ruiz@ehu.eus (A.R.-G.); igone.palacios@ehu.eus (I.P.-A.); daniel.zuazagoitia@ehu.eus (D.Z.)

* Correspondence: arantza.rico@ehu.eus; Tel.: +34-945-014-188

+ These authors contributed equally to this work.

Abstract: This article presents an interdisciplinary teaching-learning sequence (TLS) about air quality for pre-service primary teachers using an organic learning garden. The design involved a curricular integration of concepts and competences about sustainability, mathematics, and science disciplines following constructivist and active learning strategies, such as problem-based learning and placebased education. In this TLS, both the topic and the learning context act as facilitators of education for sustainable development (ESD). The contents address the overarching STEM and sustainability concepts related to air pollutants, weather, and climate. Our results show that students learned about a STEM topic within a space and context that enables ESD. Several misconceptions related to air quality, weather, and statistics were identified through the evaluation of students' initial ideas. Furthermore, students' attitudes towards the topic of study and self-efficacy and perceived relevance of ESD improved after the implementation. These results will guide further improvements of the designed TLS, which connects STEM education and ESD as a transformative educational experience for pre-service teachers. In this sense, we conclude that such initiatives can improve pre-service primary teachers' self-efficacy as agents of change towards sustainable development goals.

Keywords: STEM education; education for sustainable development (ESD); transformative learning; problem-based learning (PBL); place-based education; sustainable development goals (SDGs); organic learning gardens; pre-service primary teachers

\section{Introduction}

In the words of UNESCO, the momentum for education for sustainable development (ESD) has never been stronger. Global issues—-such as climate change-urgently require a shift in our lifestyles and a transformation of the way we think and act [1]. To achieve this change, higher education has a key role to play, as higher education institutions not only prepare employable professionals, but also face the challenge of educating reflective citizens who will contribute towards the 2030 Agenda for Sustainable Development [2,3]. In this sense, education for sustainable development (ESD) is a transformative education that offers new ways to see the world, and involves the development of systemic, critical, and creative thinking and the empowerment of citizens for decision-making in the construction of alternative sustainable futures [4]. The effort to integrate and promote competences for sustainability in higher education has been considerable [1,2,5-9], especially since the United Nation's call to "transform our world" through the commitment towards sustainable development goals (SDGs) [3]. Despite recent significant advances, further research, guidance, practice sharing, and empirical studies are required for a better 
understanding of how ESD may be successfully implemented in higher education $[9,10]$. Our paper addresses such a gap, and is motivated by the following: (1) the scarceness of published studies that explore and assess how to properly connect the principles of ESD and STEM education, and (2) the necessity of empirical works that deepen in the design and improvement of teaching and learning processes to connect competences and key pedagogical approaches for ESD.

Regarding the first point, that is, the need to assess the potential of interconnecting ESD and STEM education at the university level, it is important to bear in mind what we understand as STEM education. STEM has been defined as a meta-discipline, in which, taking the standards as a reference, teachers of the STEM disciplines (i.e., science, technology, engineering, and mathematics) address content in an integrated way [11]. Other authors regard STEM educational strategies as a way to tackle pressing socio-political challenges, such as the lack of vocations towards STEM professions among students, or the lack of scientific literacy in the general public, rather than a methodology itself [12]. We understand STEM as an educational perspective, and agree with Pérez-Torres and collaborators that STEM approaches to teaching and learning should respect the epistemic nature of each discipline, that is, the different STEM practices (ways of doing, thinking, and talking in science, mathematics, or engineering) that students need to mobilize and learn in a particular context [13]. In the case of pre-service primary teacher training, this acquires a special relevance, as they will be generalist teachers [14].

Interdisciplinarity, which is at the heart of STEM, and place-based education are indeed key aspects to advance in ESD [14,15], as they help students to address the increasingly complex problems related to sustainability, which encompass several technical and scientific areas [16]. Moreover, such integrative approaches using STEM practices must focus on authentic contexts and problems with the ultimate goal of finding innovative ways to address human wants and needs $[11,14,17]$, which has a great potential of alignment with SDGs. Last, but not least, the mobilization of soft skills, such as teamwork and critical thinking [12], are a few examples of common ground between STEM and ESD.

However, the integration of ESD and STEM education has been little studied and implemented, and when done so, it has usually followed very specific technical approaches [18], rather than transformative approaches. Besides, recent research on STEM education alerts us to the risk that STEM narratives of progress, competition, and innovation may entail obscuring the urgent ecological, ethical, and social justice conditions that students and society confront daily [19]. Furthermore, some authors [19,20] stress the need to include critical reflection in STEM education to allow for proper alignment with SDGs.

Regarding the second point, that is, the design and empirical evaluation of proposals that address ESD, while it is true that the paradigm shift involved in achieving SDGs can only occur through education [1], it is also true that to be transformative, education should rely on active and student-centered teaching and learning strategies $[5,6,21]$. In the end, sustainability issues deal with knowing the problems the planet and its inhabitants are experiencing, and about being able to collaborate in finding solutions to achieve the SDGs [5]. Thus, methodologies such as problem-based learning (PBL) help in that direction. This also applies to higher education, where PBL and other active methodologies are suggested as a way to achieve competences for sustainability and connect with SDGs in its teaching praxis $[8,9,22]$. Hence, the need to deepen in the design, implementation, and improvement of such teaching and learning processes.

\section{Education for Sustainable Development with Pre-Service Primary Teachers}

We would also like to emphasize the relevance of improving the pedagogical content knowledge about sustainable development (SD) in teacher training at higher institutions. On one hand, it is paramount to transform teacher education to promote SDGs [23]. On the other hand, we bear in mind the social multiplier effect that teaching pre-service primary school teachers has, so they downstream their learning as future educators [24]. ESD requires professionals capable of activating competences and capable of generating new 
teaching and learning scenarios coherent with the principles of sustainability [25]. However, it is not without difficulties. Albareda and collaborators [5] argue that teaching based on competencies for sustainability presents a new challenge for university teachers and, more particularly, for those who teach future teachers. Future teachers not only need to know about the problems related to sustainability, they also need to have acquired the necessary competencies for sustainability and to teach leading by example $[5,26]$. Furthermore, they must become dynamic members of the classroom, in which they engage in dialogue with students, their parents, and the community [2]. To do so, the use of active teaching and learning strategies, as key pedagogical approaches for SD, is required. Taking into account the potential of interdisciplinarity for ESD $[5,23,27]$, we present a teaching-learning sequence (TLS) that connects STEM education and ESD as a transformative educational experience for pre-service teachers.

Our TLS follows a constructivist approach, and benefits from active teaching and learning strategies, such as problem-based learning (PBL), which is known to increase students' performance in STEM concepts and practices [23]. As a key pedagogical approach for ESD in pre-service primary teachers, we incorporate learning outside the classroom [28]. We use the organic learning garden (OLG) at our campus as a community context, where interdisciplinary concepts can be taught to solve a real and relevant problem [29]. The sense of place, that is, the experiential character of the learning process, has been shown to increase the interest, understanding, and academic outcomes of the content to be taught [30]. An OLG as a learning context for pre-service primary teachers is of special relevance regarding the acquisition of contents and competences in ESD, which will be transferred to their future professional practice [14,31,32]. Additionally, OLGs represent an opportunity for mainstreaming ESD connected to STEM education, because many schools have a learning garden, which is not always the case for laboratories or other educational spaces. In fact, OLGs are expected to allow students to gain outdoor learning experiences [32]. Therefore, knowing how to carry out pedagogical projects with an ESD and a STEM focus in mind is of great importance for pre-service teachers if they want to contribute to a transformative education [1,31].

The air quality in our campus and the extraordinarily warm February in VitoriaGasteiz city (Basque Country, Northern Spain) in 2019 is the topic around which the TLS revolves. The starting point is, therefore, a real situation that took place in the students' close context. Besides, it seems appropriate to include in our TLS contents related to several SDGs [1], as they are comprehensive enough to be addressed from a holistic viewpoint using active teaching and learning strategies [5]. Air quality provides a useful context to link the students' learnings with SDG13 — climate action, SDG3 - good health and well-being, and SDG11-sustainable cities and communities. Particularly, the air's concentration of pollutants, such as ground ozone and particulate matter, has been proven to be an interesting topic in sustainable educational models with both secondary education students [33] and graduate students [34], and a few citizen-science initiatives point to the potential of using OLG to assess air quality issues [35]. Furthermore, the scarcity of studies available [36] suggests that several misconceptions may exist regarding the nature of such pollutants and their links with health and climate change. Likewise, the topic of air quality allows connecting local issues to global problems, due to its link with climate change and with SDG 13. This connection can improve pre-service primary teachers' capacity for decision making and action at the local level, with implications at the global level, enabling critical thinking and collective youth action to reverse climate change (e.g., Fridays for Future) [37].

To summarize, we present the design of a curricular integration of STEM disciplines and competences for ESD, following constructivist and key pedagogical approaches for sustainable development. Furthermore, we aim (1) to detect pre-service teachers' ideas related to air quality, weather, and climate using as context the OLG based on our campus; and (2) to evaluate and improve the quality of the designed TLS by assessing students' learning outcomes and students' self-efficacy and perceived relevance about ESD. 


\section{Design and Curricular Integration of the STEM-ESD-TLS about Air Quality}

In this paper we present the design, pilot implementation, and evaluation of an interdisciplinary approach to ESD through STEM disciplines for undergraduates in primary education about air quality, using the OLG based on our campus as context. For the design of such teaching and learning processes, we take into account Sterling [38] and Lozano and collaborators' views [22] that such curricular integration of sustainability should allow for:

1. Understanding the principles of sustainable learning.

2. Identifying key issues in sustainability in each discipline or area of knowledge.

3. Creating opportunities for students to develop skills for sustainability.

4. The use of key pedagogical approaches for sustainable development, such as PBL and place based education.

5. Experimenting with interdisciplinarity.

6. Being a part of the university or school community.

Likewise, we follow problem-based learning as a constructivist pedagogy that helps increase student performance in STEM, and, at the same time, is considered a key pedagogical approach for SD $[21,22,27,39]$. The principles that guide the STEM-ESD-TLS are the following [40]:

1. The involvement of students in solving a practical and relevant problem.

2. The inclusion of active methodologies and collaborative learning.

3. The incorporation of information and communications technologies (ICTs).

4. A focus on meaningful and highly complex learning.

Our proposal is also anchored in our reliance on the process of TLS design as a strategy to assess the quality of the product for future refinement in an iterative fashion. This allows the implementation of teaching strategies that rely on educational empirical evidence. In that sense, we understand our proposal as a product of research and innovation, and adopt the term of TLS by Psillos and Kariotoglou [41], which is defined as "both an interventional research activity and a product, like a traditional curriculum unit package, which includes well-researched teaching-learning activities empirically adapted to student reasoning".

\subsection{Curricular Integration of STEM and Competences for Sustainability Education}

Table 1 shows the curricular integration of STEM and ESD contents and competences and its alignment with SDGs $[1,25]$. The process of integration is comprised of two steps. Firstly, common curricular content that has been traditionally delivered in separate disciplines was identified alongside transversal competences for the degree in primary education and specific competences relating to mathematics and science education courses [42]. Methodological considerations, such as the use of key pedagogical approaches for sustainable development (PBL and place based education) and an understanding of key topics in sustainability for a particular knowledge area and linked with learning objectives for SDGs $[1,22,38]$ were taken into account. This means that students acquire the objectives stated in their syllabus while developing interdisciplinary skills belonging to ESD and a series of values and attitudes regarding sustainability. Finally, the STEM-ESD-TLS must focus on the students' learning process and the application of the acquired knowledge because it is paramount for the competences to be achieved [43]. 
Table 1. Integration of STEM and ESD concepts and competences in a teaching learning sequence about air quality and weather.

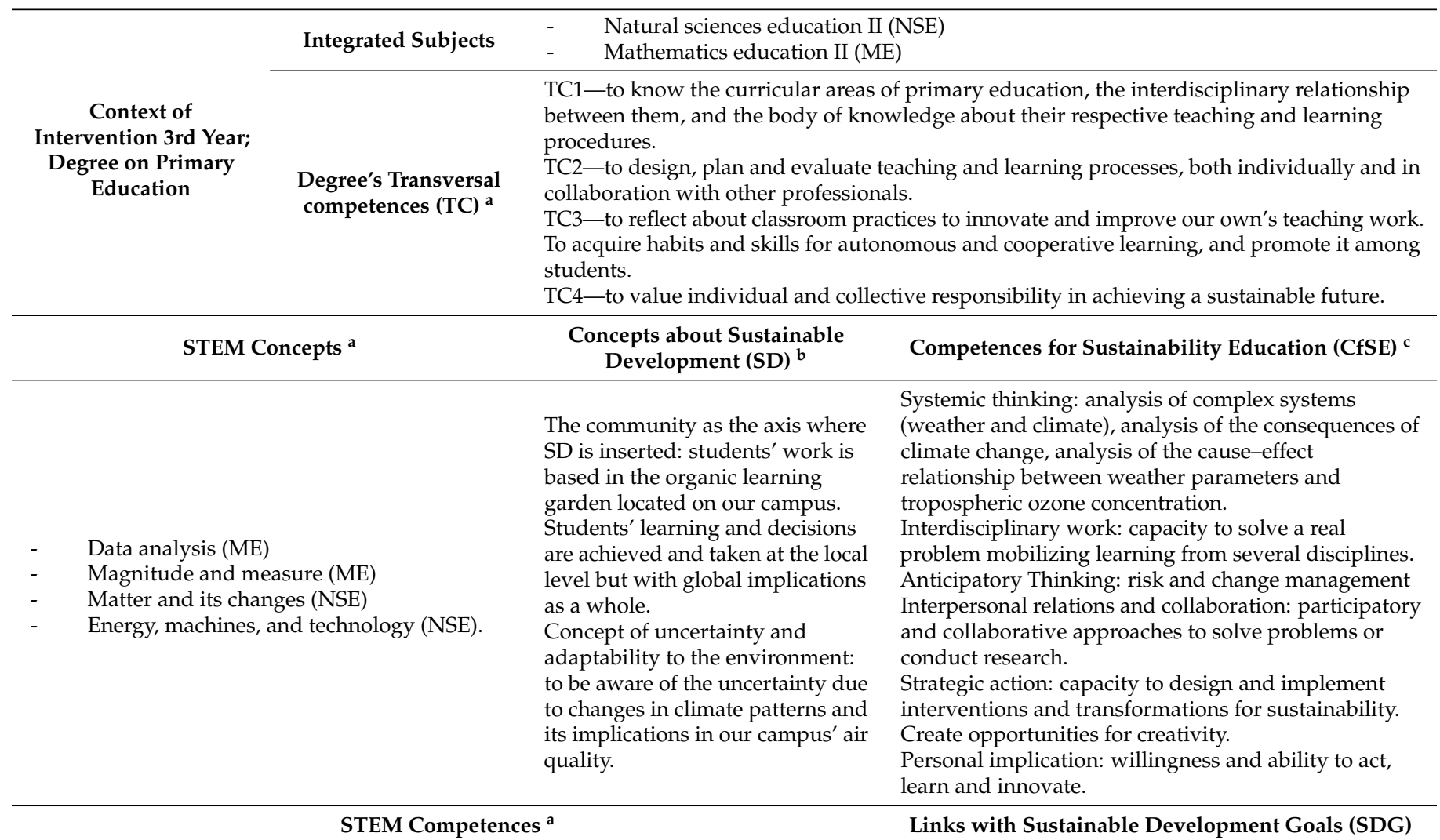

ME1-to know the appropriate methodological strategies to develop

logico-mathematical thinking.

ME2 - to know the elementary mathematical contents corresponding to the primary

school curriculum: measurement, calculation, and estimation of magnitudes and

treatment of information

NSE1 - to learn the basic principles and laws of experimental sciences.

SDG3 - good health and well-being

SDG4-quality education

SDG11 - sustainable cities and communities

SDG13-climate action.

NSE2 - to raise and solve problems related to everyday life.

a The transversal competences, the STEM concepts, and STEM competences are defined in the syllabus of the degree of primary education [42]. ${ }^{b}$ These concepts are adapted from fundamental sustainability principles as defined by [43]. ${ }^{c}$ Adapted from [22].

\subsection{The Context of the TLS and Guiding Problems}

The real scenario that prompted the TLS was as follows:

"In February 2019, the temperatures recorded in Vitoria-Gasteiz were significantly higher than those recorded at that time in previous years. The media published news that said that in February the permitted hourly limits of air pollution exceeded on several occasions, that the air quality was becoming "bad" or "very bad" and that the quality of the air worsened due to the good weather and the lack of rain and clouds."

To learn how to teach about data analysis, climate, and weather and sustainability issues, two guiding problems (Figure 1) were posed to the students, which involved (i) the understanding of air quality and its relation with the weather and climate change, and (ii) the understanding of weather parameters to be able to teach about them using sensor technology for the primary classroom. 
PROBLEM 1

PROBLEM 2

\begin{tabular}{|c|c|}
\hline 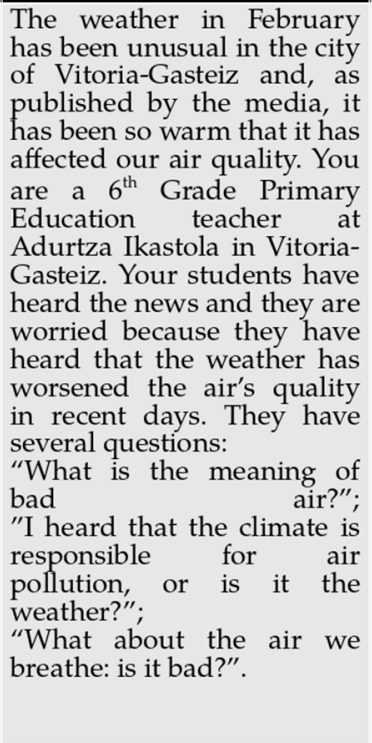 & $\begin{array}{l}\text { You are a } 6^{\text {th }} \text { Grade Primary } \\
\text { Education teacher at } \\
\text { Adurtza Ikastola in Vitoria- } \\
\text { Gasteiz. In your school, } \\
\text { different sensors have been } \\
\text { purchased through a } \\
\text { Basque Government STEM } \\
\text { grant from the Department } \\
\text { of Education, but } \\
\text { apparently none of the } \\
\text { teachers has used them in } \\
\text { their classes. You are in a } \\
\text { position to practice } \\
\text { Scientific, Mathematical and } \\
\text { Technological competence } \\
\text { and want to incorporate it } \\
\text { into your teaching planning. } \\
\text { The proposed task is: } \\
\text { "Which magnitudes/ } \\
\text { variables can we measure? } \\
\text { What teaching-learning } \\
\text { activities can we prepare to } \\
\text { explore the environment } \\
\text { and weather of our school? } \\
\text { Which could be the learning } \\
\text { obiectives?" }\end{array}$ \\
\hline
\end{tabular}

Figure 1. The two driving problems that guide the STEM-TLS about air quality.

2.3. Design Parameters of the TLS: Alignment of Driving Problems with Learning Goals and STEM and ESD Practices

Table 2 shows a design table for the STEM-ESD-TLS, in which two main elements have been taken into account. Firstly, and as stated in the previous section (Table 1), an analysis of the curriculum and the educational context in which it is carried out is paramount to justify the inclusion of the topics related to air quality, climate, and weather in the proposal [44]. Secondly, the analysis of the concepts to be taught following current explanatory models allows defining specific learning goals for our context [41]. The theoretical explanations of the STEM concepts covered in the proposal are shown in Results section. Further criteria for the design of the TLS is summarized here:

1. Driving questions are the questions that will guide the process to solve the problem. The learning goals will apply to the set of activities of those driving questions.

2. STEM practices to be carried out by the students. It refers to not to factual knowledge but to dialogical and procedural practices, that is, mathematical, scientific, or engineering ways of doing, thinking, or speaking [13,15,45,46].

3. Activities. A brief explanation of the activities performed.

4. Attitudes and values about ESD [43].

5. Methodologies that promote STEM and ESD [22].

This TLS was carried out with pre-service primary teachers enrolled in two subjects during the same academic term and was delivered through a system of co-teaching by two authors of this paper, who are mathematics and science education lecturers, respectively. After presenting the scenario and the two guiding problems (Figure 1), students worked mainly in groups of four to five during seven sessions (1 ECTS). Some sessions were held in the classroom and others in the OLG. In these sessions, students learned about air quality, climate, and weather using statistical parameters, sensor data gathering, and data analysis tools (Table 2). Data collection and analysis by students had special relevance, as students learned to access governmental databases and compile, organize, and analyze data to make conclusions about the topic, which helped them to develop STEM concepts and competences [46-48]. 
Table 2. Driving problems and sequence of activities for the STEM-ESD-TLS.

\begin{tabular}{llll}
\hline \multicolumn{1}{c}{ Driving Problems/Questions } & \multicolumn{1}{c}{ Learning Objectives } & \multicolumn{1}{c}{ STEM Practices } & \multicolumn{1}{c}{ Activities } \\
\hline $\begin{array}{l}\text { (1) What is the meaning of bad } \\
\text { air quality? }\end{array}$ & $\begin{array}{l}\text { (1) To learn about the main } \\
\text { pollutants that affect air quality. }\end{array}$ & $\begin{array}{l}\text { Scientific inquiry: mobilize } \\
\text { previous knowledge }\end{array}$ & $\begin{array}{l}\text { Students answer a pre-test about } \\
\text { air pollutants. }\end{array}$ \\
\hline
\end{tabular}

(2) To understand that weather is the combination of several parameters such as sunlight, temperature, and precipitation in a particular region and time.

(2) What were the concentrations of the leading air pollutants in February 2019 in Vitoria-Gasteiz?
(3) To understand the influence of meteorological variables on the air's quality.

(4) To identify weather magnitudes and their units

(5) To perform data analysis of air pollutants using descriptive statistics and graphic tools. (6) To calculate an air quality index
Scientific inquiry: engaging in a scientifically oriented question Mathematical thinking: organize and summarize data, extract patterns and features, statistical data analysis.

Technology:

Use of ICT for data analysis
Students search information on the website of the Air Quality Network in the Basque Country and organize and represent data in a spreadsheet. They also analyze data from the air pollution database, selecting the stations closest to the OLG. They write a report about ground ozone levels
(3) How bad is the air we breathe near our school?
(7) To estimate the air quality based on data analysis and the analysis of threshold values (i.e., ground ozone).
Scientific inquiry: making claims based on evidence

Argumentation: construct explanations, discuss implications. Mathematical thinking: interpretation of an air quality map.

To model and make estimations with mathematics

Technology:

Use of ICT for data analysis

(2) To understand that weather is the combination of several parameters such as sunlight, temperature, and precipitation in a particular region and time.

(4) What is the difference between weather and climate?

(8) To understand that climate describes patterns of typical weather conditions over different scales and variations.
Scientific inquiry: engaging in a scientifically oriented question.
Students prepare the response to an imaginary sixth grader based on their data analysis.

There is a group discussion about air quality, sustainability, and education.

Students fill in the post-test about air pollutants.

Students answer a pre- and post-test about situations related to weather or climate.

Students make a list of atmospheric conditions that influence weather and identify the physical magnitude that has to be measured.

In pairs, students describe a weather magnitude including its units of measurement. Students apply the kinetic molecular theory of matter to explain cloud formation in a short report.

Students choose a location on the campus to take measurements and assess relationships between weather variables. One of these locations is the OLG.

Students contrast their sensor-based data with the data collected in weather stations and with predictions by weather agencies.
(6) How can we collect weather data and describe or predict the weather around us?
(5) To learn how to use weather sensors that can be used in a school setting.

\section{design.}

Understand cause-effect

relationships.

Making claims based on evidence.

Mathematical thinking:

measurements.

Data analysis.

Use of ICT: sensor technology

\section{Attitudes and Values about ESD}

\section{Methodologies Used for} STEM and ESD
Identify key issues about sustainability in the project;

create opportunities for students to develop skills for sustainability;

the use of key pedagogical approaches for sustainable development; work in an interdisciplinary problem.

Socioconstructivist: starting from initial knowledge and taking into account the social context of the development and learning of students;

participatory and collaborative;

the use of digital technologies for measuring parameters;

context-learning - many activities are carried out in the OLG 


\section{Materials and Methods}

\subsection{Participants}

This TLS was put into practice with students enrolled in the 3rd year of the bachelor's degree in primary education in the Faculty of Education and Sport of the University of the Basque Country, UPV/EHU, located in the city of Vitoria-Gasteiz (northern Spain). The teaching-learning sequence was implemented in a cohort of 24 students effectively attending two courses: mathematics education II and natural sciences education II. Eleven students were women (39\%) and thirteen were men (46\%). They were all 20-25 years old. The second and third authors of this paper were the lecturers responsible for each course, respectively, and were involved in the co-teaching activities. This TLS has been implemented during a single academic year (2018/2019) as a pilot implementation.

\subsection{Materials}

For air quality data analysis performed by students, data from the Basque Government Air Quality Network were used (https:/ / www.euskadi.eus/web01-a2ingai2/eu/ aa17aCalidadAireWar/estacion/mapa?locale=eu, accessed on March 2019). In particular, a measuring point located very close to the OLG was used. For analysis of weather parameters, data from a weather station belonging to the Basque Weather Station Network (https: / / www.geo.euskadi.eus / red-de-estaciones-meteorologicas-de-euskadi/s6 9-geodir/es/, accessed on March 2019) and located in the university campus were used. For weather data collection within the OLG, temperature, humidity, air pressure, and wind sensors (Pasco Scientific, Roseville, CA, USA) attached to hand-held tablets were used by students. Sparkvue data collection systems (Pasco Scientific, USA) were used to collect and plot the data. Table 2 shows detailed information of the activities performed both in the classroom and in the OLG.

\subsection{Evaluation of the Implementation of the STEM-ESD-TLS}

To evaluate the quality of the designed TLS, questionnaires about STEM-related content, and a quantitative response questionnaire to assess students' satisfaction about the STEM-ESD proposal were administered post-implementation. Self-efficacy and perceived relevance of ESD was measured pre- and post-implementation. All surveys were designed and administered online through Google Forms. Data collection was conducted under the supervision of two researchers (E.A.-B and A.R.-G) and the questionnaires were administered online during regular classroom sessions. Data analysis was performed using a spreadsheet software (Microsoft Excel).

\subsubsection{Questionnaires about STEM-Related Content}

Pre- and post-implementation questionnaires were administered to measure students' knowledge about weather and climate (Table S1). A total of 17 students answered both questionnaires. The questionnaires contained five identical items and included dichotomous, multiple choice, and open-ended questions. Some questions included a section for justification. For example, the first question (Q1) is based on the formative assessment probe "Are they talking about climate or weather"? by Keeley and Tucker [49], see Table S1, which inquires whether students can differentiate between weather and climate by assessing 8 situations from everyday life. After choosing one of the two options for each situation, students were asked to explain their criteria for differentiating between weather and climate. The second (Q2) and third (Q3) questions asked to enumerate specific air pollutants and weather variables, respectively. The fourth question (Q4) was a multiple-choice question (Yes, No, I do not know) and inquired about whether meteorological variables affect air quality. Afterwards, students were asked to justify their choice of answer by giving examples. The last question was open-ended (Q5) and asked the students about their thoughts about the air quality in our campus. This allowed for detecting pre-service teachers' misconceptions related to air quality and weather and, afterwards, assessing learning outcomes. 
3.3.2. Survey to Evaluate Student's Self-Efficacy and Perceived Relevance of ESD and Satisfaction with the Learning Process

A quantitative response questionnaire to assess students' satisfaction with the STEMESD-TLS, as well as their attitudes towards STEM and sustainability, was administered six weeks after the implementation, which was answered by 14 students. First, students were asked to give a general score from 1 to 10 to the STEM-ESD-TLS. Secondly, they were asked to evaluate 4 aspects of the TLS following a 5-point Likert scale (from 1-very bad to 5-very good): 1, the program and general contents; 2 , the methodology used; 3 , the classroom atmosphere and participation within the group; and 4, the teacher's role. Thirdly, they were asked to express their interest in the topic before and after the implementation following a 5-point Likert scale (from 1-very little to 5-very high). Finally, students had to fill out a compulsory section for further suggestions and improvements to the STEM proposal.

The second part of the questionnaire inquired about students' self-efficacy and perceived relevance of ESD. This part was administered pre- and post-implementation. Two questions from Tomas and collaborators' study [50] with pre-service teachers were used to assess students' attitudes towards ESD (see Table S2). Specifically, the question about self-efficacy in ESD presented students with 7 tasks where they had to express how easily they thought they would perform them following a 4-point Likert scale. Another question inquired about students' perceived relevance of ESD by asking about their level of agreement with 6 statements following a 4-point Likert scale. In all cases, an open text section was available for the justification of students' responses. Frequency distributions from Likert items were calculated for each question.

\subsection{Data Analysis}

Data analysis followed a mixed-methods approach combining quantitative and qualitative measurements. For dichotomous, multiple-choice questions or Likert-type items, frequency distributions were calculated for each level. Regarding the answers for openended questions in the STEM-related content questionnaire, these were graded using the scoring system first shown in Table S1, and descriptive statistics were calculated for each data set (pre- and post-data; see supplementary Table S3). Secondly, participant responses to open-ended questions were analyzed and distributed into categories that reflected different levels of reasoning. These categories emerged from the data, and if necessary, new ones were introduced [51]. The data were assessed independently by the first and second author to build a common understanding of how to describe it. Frequency distributions of each category pre- and post-implementation were calculated for each question.

\subsection{Ethical Considerations}

All participants who completed the questionnaires were university students, aware of the purpose of the research and over the age of 18 years. Consent was provided by participants by signing an informed consent form delivered at the beginning of the implementation. This study was performed within the UPV/EHU during academic hours and received ethical approval by the ethics committee. A registry of the consent documents signed by the subjects of this research and the files used in the research is kept in the Data Protection Unit of the UPV/EHU.

\section{Results}

\subsection{Evaluation of the STEM-ESD-TLS through Knowledge-Based Questionnaires}

Following the scoring system detailed in Table S1, our quantitative data shows that, overall, students' specific knowledge about air quality and meteorology improved after the implementation (Figure 2).

In that sense, Figure $2 \mathrm{~A}$ shows that more than half of the students obtained scores higher than 5 in the pre-test, and 16 out of 17 scored higher than 5 in the post-test. Regarding the minimum scores, these were 3.8 in the pre-test and 5.0 in the post-test (see Table S3); in 
the pre-test, 4 students out of 17 did not exceed the minimum; whereas, in the post-test, all students exceeded that threshold.

A

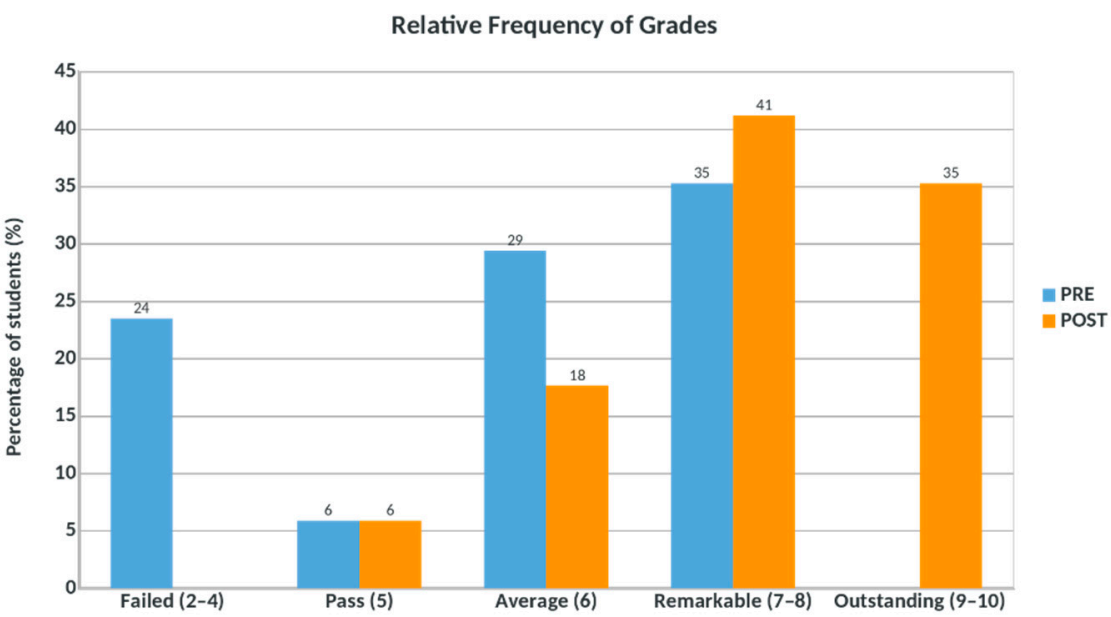

B

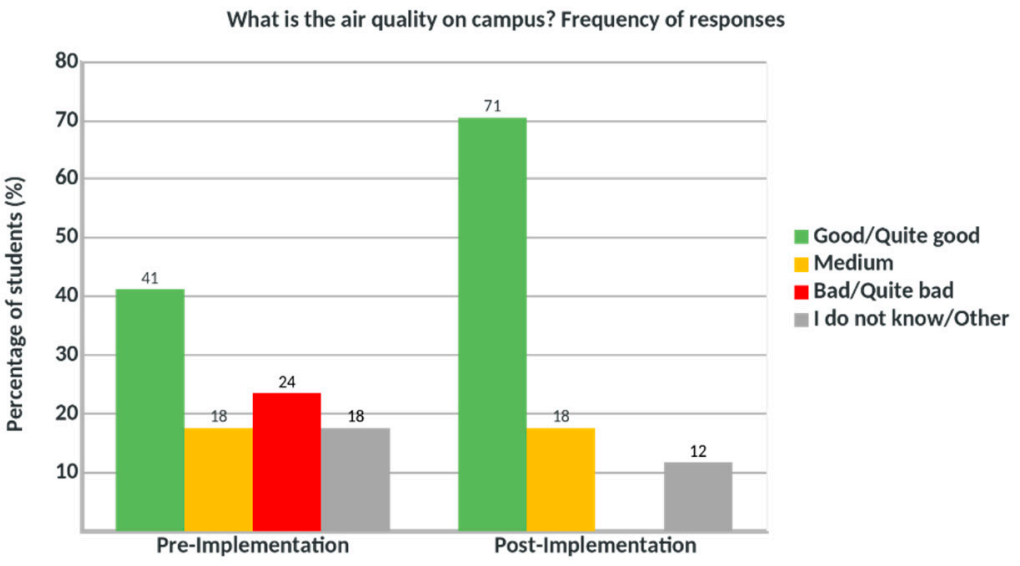

Figure 2. Results from the STEM knowledge questionnaire $(n=17)$. (A) Frequency of students' grades calculated from the scores (1 to 10) in the five-item STEM knowledge questionnaire. (B) Frequency of responses about the air's quality on campus. Green bars indicate the correct answer.

An analysis of descriptive statistics was performed for the pre- and post- data, which showed that the arithmetic mean and median were higher in the post-data with identical standard deviation for both data sets, which reinforces the idea that the performance was higher after the didactic implementation (see Table S3). Moreover, first- and third-order quartiles show that $50 \%$ of the scores in the post-implementation survey were between 7 and 9 , while $50 \%$ of the data in the pre-test varied between 4 and 7 , which indicates that, after the TLS implementation, there was lower variance between quartiles and higher score values (Table S3).

The detailed analysis of the first question of the questionnaire (Q1), aiming at measuring climate vs. weather knowledge (see Table S1), and taking the presented eight situations as a whole, shows a good baseline knowledge pre-implementation (70\% correct) and an overall slight improvement post-implementation (77\% correct). Some of the situations aimed to detect whether students incorrectly assigned dramatic weather events such as snowstorms and floods to climate. In this regard, the correct answer (weather) to statement Q1-G: "News flash! The drought in Spain has ended with the first significant storm this year dumping more than $250 \mathrm{~mm}$ of rain in many locations and filling most of the reservoirs to pre-drought conditions." improved from $53 \%$ in the pre-test to $71 \%$ in the post-test. However, with regard to Q1-D (Table S1), 13 students out of 17 still related extreme weather events, such as snow in spring, incorrectly to climate. Nevertheless, 
the analysis of students' reasoning showed that there was an improvement in the way students explained the difference between weather and climate (Table 3). For example, in pre-implementation answers, most of the explanations referred to weather as "something specific", and saw climate as "something general". In post-implementation answers, the number of explanations that included particular daily atmospheric conditions for weather and mentioned geographical factors or average values of atmospheric parameters for a long time in a given region to refer to climate increased.

Table 3. Students' reasoning in the open-ended section of question Q1 of the STEM knowledge questionnaire: "Which criteria would you use to decide whether the statements above refer to climate or weather?".

\begin{tabular}{|c|c|c|c|}
\hline $\begin{array}{c}\text { Types of } \\
\text { Reasoning }\end{array}$ & Pre-Test (\%) & Post-Test (\%) & Examples Given by Students \\
\hline $\begin{array}{c}\mathrm{C} 1-\text { Full } \\
\text { explanation a }\end{array}$ & 29.4 & 47.1 & $\begin{array}{l}\text { "Weather is what you get at the } \\
\text { moment or on a given day (rain, } \\
\text { temperature,...) and climate, for } \\
\text { example, are data received over the } \\
\text { years (average temperature, etc.)" } \\
\text { "Climate: data collected over the } \\
\text { years, more general; Weather: what } \\
\text { you get in one day: specific." } \\
\text { "Weather takes into account the } \\
\text { atmospheric condition of a particular } \\
\text { area. Climate, on the other hand, } \\
\text { takes into account the data taken over } \\
\text { time in a particular area". }\end{array}$ \\
\hline $\begin{array}{c}\mathrm{C} 2 \text {-Weather is day } \\
\text { specific, climate is } \\
\text { general }\end{array}$ & 41.2 & 29.4 & $\begin{array}{l}\text { "Weather is a one-time event, climate } \\
\text { is more general." } \\
\text { "when it is a thing of the day it refers } \\
\text { to the weather, but when it is more } \\
\text { general it refers to climate." }\end{array}$ \\
\hline $\begin{array}{l}\text { C3-Partial } \\
\text { explanations }\end{array}$ & 29.41 & 17.6 & $\begin{array}{l}\text { "I call weather a sensation of the } \\
\text { moment or a climate of the moment". } \\
\text { "I've connected weather with the } \\
\text { feeling it will have at a given time } \\
\text { and climate to the conditions that are } \\
\text { in a certain environment." }\end{array}$ \\
\hline $\begin{array}{l}\text { C4-Incoherent } \\
\text { answer }\end{array}$ & 0 & 5.9 & “Time” \\
\hline
\end{tabular}

Regarding the open-ended question (Q2) on air pollutants (see Table S1), the analysis of the students' reasoning before and after the implementation allowed for establishing two categories of growing complexity. The first category included those answers that correctly mentioned specific air pollutants, or generic elements such as smoke or exhaust gases. The second category was designated as "sources" because the answers refer to common sources of pollution, such as factories, agriculture, farming, or transport, rather than specific air pollutants. In both cases, students might or might not mention gases that contribute to global warming such as carbon dioxide or methane, or their anthropocentric sources. Before the intervention, $76 \%$ of the answers were allocated to "sources", followed by generic mentions to air pollutants, such as smoke, residues, or aerosols $(24 \%)$. None of the students mentioned specific pollutants, such as ozone or particulate matter. After the intervention, $71 \%$ of the answers correctly addressed the question and included specific air pollutants (Table 4). In fact, the levels of the most relevant air pollutants on campus were looked up during the intervention. Nearly a third of the students that correctly enumerated air pollutants, such as ozone or particulate matter, included global warming gases as well, such as carbon dioxide and methane. 
Table 4. Students' reasoning to open-ended section of question Q2 of the STEM knowledge questionnaire: "What are the leading air pollutants in the Basque Country?"

\begin{tabular}{|c|c|c|c|}
\hline Types of Reasoning & Pre-Test $(\%)$ & Post-Test $(\%)$ & Examples Given by Students \\
\hline $\begin{array}{l}\text { C1-air pollutants } \\
\text { (generic or specific) }\end{array}$ & 24 & 71 & $\begin{array}{l}\text { Generic: "The waste emitted by } \\
\text { the companies, the gases emitted } \\
\text { by the cars, the indiscriminate } \\
\text { consumption of plastic carried out } \\
\text { by society, the lack of recycling } \\
\text { habits of people, etc." } \\
\text { "The smoke from industries, cars" } \\
\text { Specific: "Nitrogen dioxide, ozone, } \\
\text { sulfur, carbon dioxide, methane". } \\
\text { "Ozone, PM10, PM2.5". }\end{array}$ \\
\hline C2-sources & 76 & 29 & $\begin{array}{l}\text { "Transport, agriculture, farming, } \\
\text { industries" }\end{array}$ \\
\hline
\end{tabular}

Regarding question Q3 (Table S1), before the implementation, students knew only a few of the main weather parameters, and mentioned primarily temperature (all the students), precipitation ( $88 \%$ ), wind speed or direction, and humidity $(47 \%)$, followed by atmospheric pressure (35\%). Ultraviolet radiation was rarely mentioned ( 2 students). After the didactic implementation, the mentions of atmospheric pressure increased to $60 \%$ and UV radiation increased to $24 \%$.

When asked about the relationship between the weather variables and the air's quality (question Q4, Table S1), before the implementation, $47 \%$ of the students gave answers related to precipitation "as a way of cleaning the air", but no mention was given to the role that temperature and humidity have on tropospheric ozone concentration (Table 5). After the implementation, the stances that mentioned the role of temperature in tropospheric ozone concentration increased to $35 \%$.

Table 5. Students' reasoning to open-ended question Q4 of the STEM knowledge questionnaire: "Do meteorological variables affect air quality? Reason your answer and give examples".

\begin{tabular}{|c|c|c|c|}
\hline Types of Reasoning & Pre-Test (\%) & Post-Test (\%) & Examples Given by Students \\
\hline $\begin{array}{l}\mathrm{C} 1-\text { precipitation } \\
\text { related to cleaner air }\end{array}$ & 47 & 29 & $\begin{array}{l}\text { "It is usually rain that cleans the atmosphere, so } \\
\text { if it rains the quality of our air will be better, } \\
\text { since the pollution is alleviated." } \\
\text { "Air pollution goes down with rain, and air's } \\
\text { pollution is slightly cleaned. }\end{array}$ \\
\hline $\begin{array}{l}\text { C2-high temperatures } \\
\text { and dry conditions } \\
\text { favour tropospheric } \mathrm{O} 3 \\
\text { accumulation }\end{array}$ & 0 & 35 & $\begin{array}{l}\text { "When the temperature is high, ozone increases } \\
\text { and air quality is worse" } \\
\text { "For example, when it rains more, the quality of } \\
\text { ozone is better, which means less pollution. } \\
\text { And on sunny days there is a lot of ozone, so } \\
\text { the quality of the air is worse" }\end{array}$ \\
\hline $\begin{array}{c}\text { C3-other factors, such } \\
\text { as acid rain. }\end{array}$ & 21 & 18 & $\begin{array}{l}\text { "Yes, because the winds that transport } \\
\text { contaminated air from one place to another will } \\
\text { affect the quality of the air. Rainfall can also } \\
\text { affect the quality of the air, for example acid } \\
\text { rain can pollute the lands that irrigates." }\end{array}$ \\
\hline $\begin{array}{l}\text { C4-Inconclusive } \\
\text { reasoning }\end{array}$ & 24 & 29 & $\begin{array}{l}\text { "Yes, sometimes the change of variables has } \\
\text { consequences in the quality of the air, for } \\
\text { example when it rains there is humidity" } \\
\text { "Because thanks to them air pollutants can } \\
\text { disappear or increase." }\end{array}$ \\
\hline
\end{tabular}

Concerning the last question about the air quality in our campus (Q5; Table S1), in the pre-implementation questionnaire, only $42 \%$ of the students inferred that the air quality was good or quite good on campus (Figure 2B), and in many cases, students used nearly the 
same reasons to claim that the air quality of their campus was good or bad (see examples in Table 6); in the post-questionnaire, all the students responded that the air quality in the campus was good or mostly good, and more than half of the students supported their claims based on evidence from air quality data collected from the Air Quality Network of the Basque Country in the studied period (Figure 2B).

Table 6. Examples of students' opinions about the air's quality in question Q5 of the STEM knowledge questionnaire before the implementation.

\begin{tabular}{ll}
\hline \multicolumn{1}{c}{ Opinion that the Air Quality Is Good } & \multicolumn{1}{c}{ Opinion that the Air Quality Is Bad } \\
\hline "The air quality in the campus in general is & "I suppose it is not good, because the campus \\
good because you cannot detect traces of & is in the city". \\
contamination". & "Considering that we are in a city, I would say \\
"I think it's good, because it's an & that it is not of great quality, even if the campus \\
uncontaminated area. There is little traffic, & is surrounded by trees" \\
there are no spillages of toxic fumes" & \\
\hline
\end{tabular}

In summary, the detailed analysis of pre-service teachers' reasoning allowed for identifying several misconceptions about air quality, weather, climate, and statistics before the implementation, and are shown in Table 7. Regarding the distinction between climate and weather, as shown earlier, the context seems to influence a proper understanding of the relationship between extreme weather events and the climate of a given region, and it merits further investigation since this lack of understanding could facilitate the acceptance of claims made by climate change deniers [52]. Regarding air pollution, many students mentioned sources rather than specific air pollutants, and the relationship between air pollutants and specific atmospheric conditions was unknown to most of them.

Table 7. Detected misconceptions in the STEM teaching-learning sequence.

\begin{tabular}{cl}
\hline Topic & \multicolumn{1}{c}{ Student Misconception } \\
\hline Climate and weather & $\begin{array}{l}\text { Climate is understood as a long-term or } \\
\text { general weather }\end{array}$
\end{tabular}
general weather

Students mention sources, such as road traffic and industries, instead of specific air

Air pollutants pollutants originating from those sources. Students identified greenhouse gases as the only air pollutants.

\section{Tropospheric (ground-level) ozone and stratospheric ozone \\ Weather parameters that affect air quality \\ Average concentration levels using the arithmetic mean}

Claims supported by evidence
Ozone is only understood as part of the stratosphere. The role of ozone in the troposphere is unknown.

Students are not aware of the positive correlation between tropospheric ozone concentration and dry and hot weather conditions

If the average daily levels of $\mathrm{PM}_{10}$ or $\mathrm{PM}_{2.5}$ are below a particular threshold, then students conclude that the air quality is good or very good.

\section{Explanation}

Weather is the combination of sunlight, wind, snow or rain, and temperature in a particular region and time. People record weather patterns over time.

Climate describes patterns of typical weather conditions over different scales and variations. Historical weather patterns can be analyzed.

Road traffic and industries are some of the sources that produce air pollution. Tropospheric ozone $\left(\mathrm{O}_{3}\right)$ and particulate matter $\left(\mathrm{PM}_{2.5}\right.$ and $\left.\mathrm{PM}_{10}\right)$ are the most relevant air pollutants in the Basque Country (https:

/ / www.euskadi.eus/gobierno-vasco/aire-medioambiente/, accessed on 15 April 2021).

Greenhouse gases produced from anthropocentric sources are also considered air pollutants.

Stratospheric ozone is not an air pollutant, because it protects us from solar radiation. Tropospheric (ground-level) ozone is an air pollutant and it can cause damage to human health and the environment.

Major episodes of high concentrations of ozone associate with slow-moving, high-pressure weather systems. These systems are also linked with high concentrations of other chemical pollutants such as sulfur dioxide.

The arithmetic mean smooths out the real variation of air pollution. The additional analysis of the minimum, maximum, and quartile values in a particular time span (February 2019) showed that, on several occasions, the air quality was not good or very good in Vitoria-Gasteiz.

Students used personal opinion instead of evidence to claim that the air quality of their campus was either good or bad.
The Air Quality Network ${ }^{3}$ contains a wide data set to establish what the air quality is in several locations of the Basque Country. Learning how to analyze and organize data allowed students to support their claims based on evidence. 


\subsection{Evaluation of Student' Self-Efficacy and Perceived Relevance of ESD and Satisfaction about the Learning Process}

Fourteen out of 17 students answered the opinion survey about the STEM-ESD-TLS using the OLG as a learning context. The survey contained four questions that inquired specifically about the TLS, and asked the students (i) to evaluate it as a whole using a scale from 1 to 10, (ii) about methodological aspects, and (iii) about their interest on the topic before and after performing the assigned tasks. In general, students responded positively to the teaching learning process, and the average score for the teaching-learning sequence was $7.36 \pm 2.13$.

When asked to evaluate the TLS, specifically about (i) the program and general contents, and (ii) the employed methodology, students responded that they were good or very good in $86 \%$ and $79 \%$ of the cases, respectively, and only three students $(21 \%)$ stated that the used methodology was average. Regarding their interest on the subject (air quality, weather, and climate) only 3 of the 14 students that filled the evaluation survey had high or very high interest about the subject before the implementation. After the TLS, the percentage of the students asserting that their interest was high or very high had increased to $64 \%$ (Figure 3).

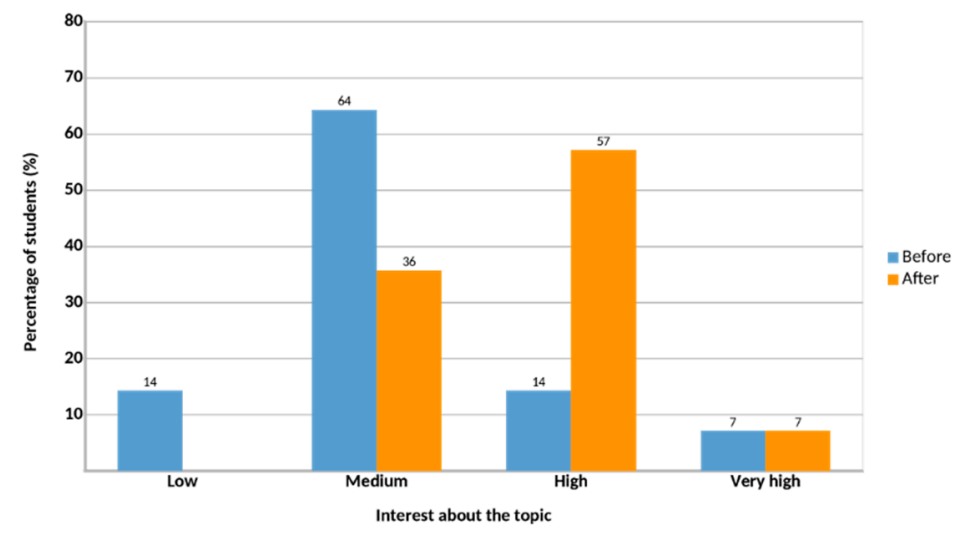

Figure 3. Evaluation of the STEM-TLS. Bars show students' interest about the topic of air quality and meteorology before (blue) and after (orange) implementing the teaching-learning sequence.

In the survey, students were also asked to express their opinions freely and give suggestions for improvements on the TLS. In general, students felt that it was interesting to integrate mathematics and science contents in a project about air quality, but felt that it was short and would have liked more sessions outdoors, particularly in the OLG. It is possible that due to the short duration of this pilot implementation, some students did not have the opportunity to reflect on the existing connections between the work performed in the classroom (mainly database searches and data analysis) and the work performed outdoors (mainly sensor utilization and data gathering).

As stated in the introduction, this STEM-ESD-TLS is an effort of curricular integration of competences for ESD in pre-service primary teachers. The fifth question of the survey presented students with a set of tasks related to SD and ESD [50] and asked them to express their perceived ability to perform them as future primary educators. In general, the posttest data show an improvement in students' self-efficacy. The responses represented in Figure 4 show that $93 \%$ of students stated that they saw themselves capable of describing "how human activities can impact the environment" easily or with little effort (Task 2, Figure 4). Similarly, $64 \%$ of these future teachers asserted that, using their knowledge and skills, they would be able to "bring about an improvement in the environment" with little effort (Task 6, Figure 4). It is also worth noting that in the post-test, $60 \%$ of students saw themselves as able to "educate others about sustainability issues" with little effort (79\%) or no effort (14\%), while only $7 \%$ felt it would be a difficult task (Task 5, Figure 4 ). 


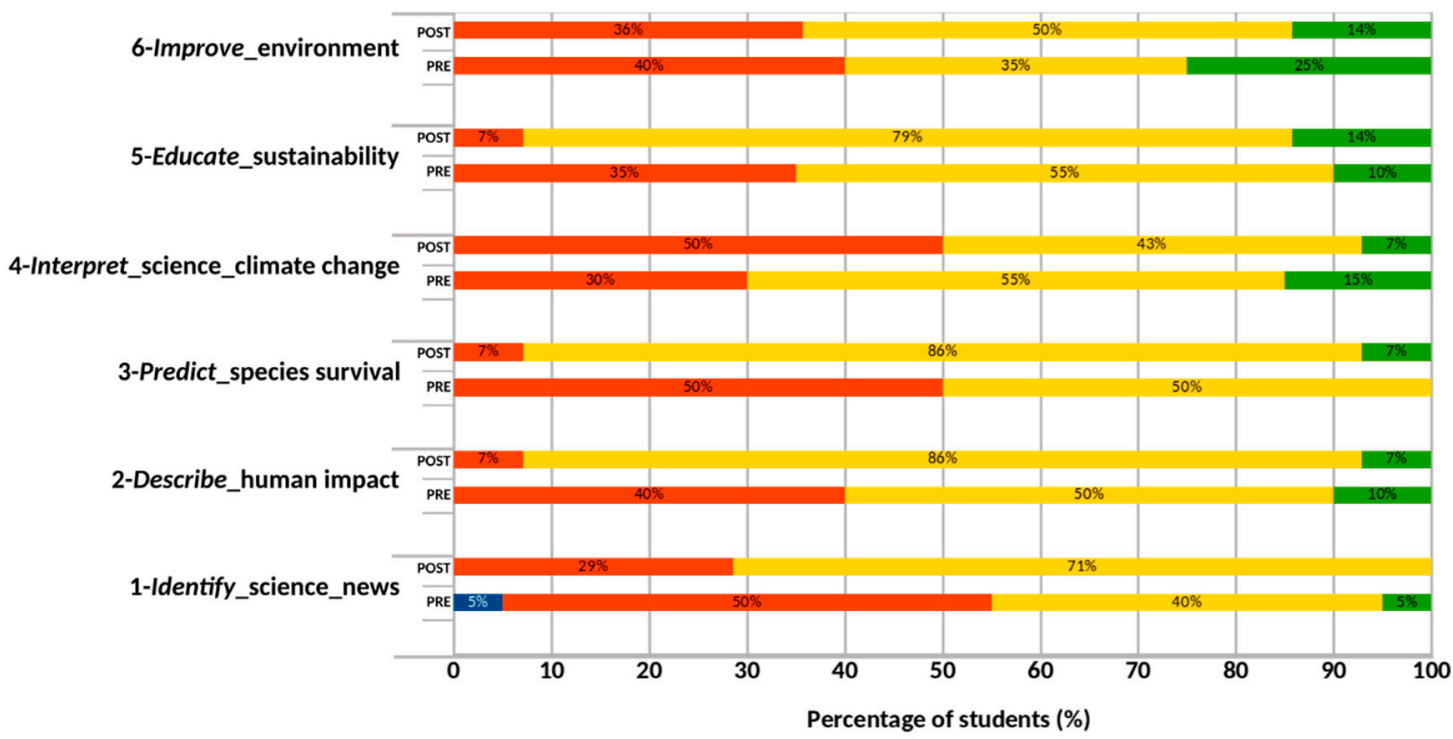

I could not possibly do it $\square$ It would be difficult to do it $\square$ I would be able to do it with a little effort $\square$ I could do it easily

Figure 4. Students' self-perceived efficacy in carrying out activities related to sustainability as future teachers. A four point Likert scale to show levels of agreement in percentages was used. The full statements are shown in Table S3.

In the following question, students were asked about their perceived relevance of ESD (see Figure 5). The increment of perceived relevance slightly increased post-implementation, such as the general disagreement that ESD is a fashionable topic that will pass over time (statement 4, Figure 5). Students also believed that it is important to teach environmental education to young students, and they considered it essential to integrate ESD into their future teaching roles (statements 3 and 2, respectively, Figure 5). In future implementations, we intend to offer students more sessions with opportunities for meta-cognition, so they would be able to make connections between the STEM-specific topics and overarching concepts about sustainability, and ultimately reflect on their learning.

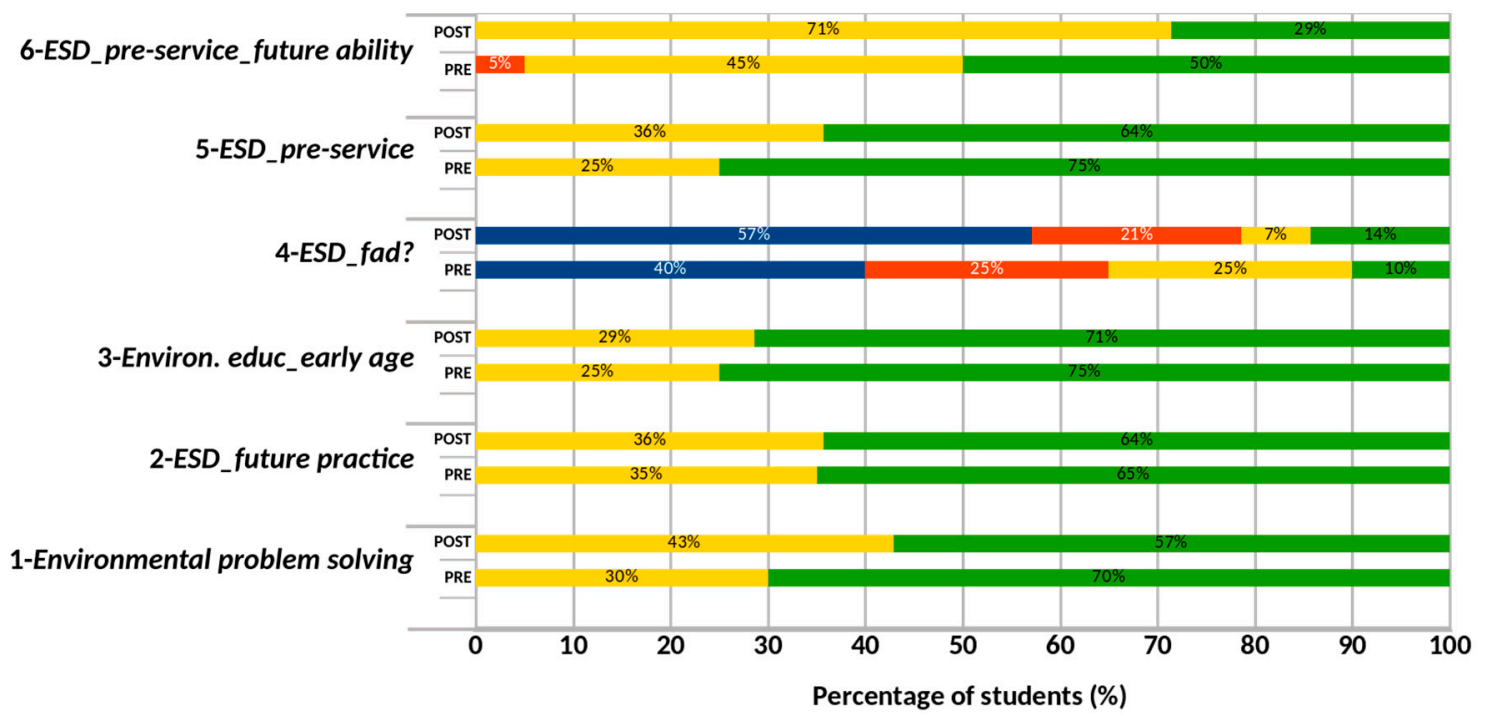

Total disagreement

Disagreement

Agreement

Total agreement

Figure 5. Pre-service primary teachers' perceived relevance about ESD. A four point Likert scale to show levels of agreement in percentages was used. The ful 1 statements are shown in Table S3. 


\section{Discussion}

5.1. Students' Learning Outcomes as a Key Tool to Improve the Teaching and Learning of Air Quality, Weather and Climate

Our pilot TLS engaged students in learning pedagogical content knowledge on mathematics, science, and technology. Through the detailed qualitative analysis of students' learning outcomes, we identified several misconceptions related to air quality, weather, climate, and statistics, which constitute a valuable resource to further refine and improve our STEM-ESD-TLS in future implementations (Table 7). The data confirms that pre-service primary teachers lacked an understanding of the relations between anthropogenic sources, climatic factors, and air pollution, and showed limited critical interpretation of numerical data. For example, before the implementation, many students mentioned the sources of pollution rather than the particular air pollutants, or identified only greenhouse gases as air pollutants. Interestingly, many of these misconceptions have been found in primary school children [36,53-55], which stresses the importance of addressing pre-service teachers' misconceptions and identifying appropriate teaching strategies for the improvement of their teaching and learning processes as key agents of social change. It is known that a source of misconceptions in primary children come from the instruction they receive [56]. Therefore, future teachers should be aware of their misconceptions, and through conceptual change, help them to reconcile their ideas with current scientific knowledge. Furthermore, as Keeley [57] stresses, capturing the conceptual knowledge of students on a particular science topic is one of the most important things that teachers (and therefore, education research) do. With this knowledge, teachers comprehend their misconceptions and can, importantly, determine what instructional strategies to use to ensure that students develop a clear understanding of a science topic [57]. An example of such teaching strategies could be avoiding the generic term 'pollution', and linking the idea of a 'pollutant' to the environmental problems it causes [53]. Regarding climate and weather, pre-implementation students tended to assign dramatic weather events to climate features, which, in turn, could be used to deny global warming $[49,58,59]$. Thus, the TLS allowed students to contrast their initial ideas and start developing a more scientifically coherent model of climate and weather. Another teaching implication related to this topic is the importance of integrating several disciplines when teaching complex issues such as climate and weather [58]. Normally, the content related to weather and climate is geography-based, so the integration of science and mathematics with other areas is key in any level of instruction, from elementary to higher education. Ultimately, incorporating scientifically coherent knowledge on these topics should help our students when reflection, or immediate and future action, on global challenges such as climate change is required.

Presenting evidence-based claims to defend a position is one of the key elements for a good argument [60]. In the beginning, students used their personal opinion to claim that the air quality of the campus was either good or bad. After the implementation, the great majority of the students were able to decide correctly based on the quality of the air on campus and to support their claims based on evidence. The fact that during the implementation students statistically analyzed the evolution of the leading air pollutants in the city of Vitoria-Gasteiz $\left(\mathrm{O}_{3}, \mathrm{PM}_{2.5}\right.$ and $\left.\mathrm{PM}_{10}\right)$ and learned about descriptive statistical parameters and statistical data graphics helped them to interpret the evidence supporting the good air quality of the campus at UPV/EHU. The use of arguments is integral in decision-making processes [61], and will help pre-service teachers to actively participate in a democratic society [62]. Therefore, thanks to such learning experiences, pre-service teachers' scientific literacy improves, which will, in turn, improve their contributionsboth personal and professional—-to the achievement of SDGs, particularly through the promotion of ESD. 
5.2. The Importance of Linking STEM Education to ESD: A Pilot Implementation in a University Organic Learning Garden

This paper presents a novel contribution and a step forward towards cross-curricular integration of sustainability and STEM education by adapting and integrating the syllabus of two independent courses in a primary education degree. Real-life issues ask to mobilize knowledge and competences that are still traditionally taught in isolated disciplines in many institutions. The interdisciplinary proposal presented here aims to surmount this contradiction through the mobilization of concepts and practices from science and mathematics to understand a problem related to air quality, and, thereafter, pre-service primary teachers must think of the problem critically and make informed decisions and propose solutions and actions where needed. The teachers involved in the implementation negotiated which part of the syllabus would be part of the co-teaching experiment and evaluated both disciplinary and transversal competences. The learning context, that is, both the problem about air quality and the OLG where the learning took place, served as the base upon which opportunities for the acquisition of concepts and competences related to education for SD arose. We also agree with Albareda-Tiana and collaborators [5] that implementations like the one presented here, which offer active teaching-learning strategies related to the SDGs in cross-curricular contexts, could help future teachers to develop competences for sustainability and ESD.

We are aware of and agree with Granados and Junyent [43] that curricular changes that integrate sustainability go beyond the mere integration of concepts or commitments towards sustainability. It implies a change of frame of mind and involves managing complex and uncertain scenarios and the integration of cognitive and emotional knowledge [63]. The evaluation of our pilot implementation showed, precisely, that the opportunities that helped students reflect about their learning and the implications as responsible citizens and professionals towards sustainability had to be more numerous and/or longer in time. The feedback received upon the implementation reinforces the idea of including more integrated STEM-ESD modules similar to the one suggested here as far as our area of action is concerned.

The importance of technology and its integration with sustainability topics was evident in our implementation. For example, students saw the importance of data analysis to measure and control air quality. Technology plays an essential role in this sense, and students used the available technology to observe the air pollutant concentrations and analyze them statistically. Furthermore, the sequence partially covered how air quality affects human health and the environment. Students showed their interest in this topic, which stresses the importance of linking STEM topics with situations that help students understand the relevance of science in everyday life and perceive themselves as agents for change towards attaining SDGs $[25,64]$.

The feedback questionnaire also showed that students' interest in STEM topics, and self-efficacy and perceived relevance of ESD, increased after the implementation. Further improvement and redesign will allow for implementing the TLS in a larger student sample and include evaluation activities and tasks that allow for effectively measuring the achievement of competences for STEM and ESD.

\section{Conclusions}

Our results show that the designed and implemented pilot TLS improved students' knowledge on air quality, weather, and climate, and supposes a step forward in the development and integration of competences in STEM and ESD. The TLS was carried out within a space and context that enables ESD. This pilot implementation with preservice primary teachers has led to two main relevant improvements of our TLS that are transferable to other ESD and STEM education processes: (1) the need for allocating more time to outdoor teaching and learning processes, particularly in organic learning gardens; and (2) the need to include meta-cognition activities to explicitly work with students on the existing link between STEM and sustainability topics. Besides, the evaluation of students' 
initial ideas allowed for identifying students' misconceptions related to air quality, weather, climate, and statistics, which allows for further improvements of this and other teaching and learning processes on air quality or climate change. The integration of ESD and STEM education through contributions such as the one presented in this paper can improve students' self-efficacy as agents of change towards SDGs when they become primary education teachers. Our data reinforce our conviction that the integration of competencies for ESD and STEM education through active teaching and learning methods in OLGs is a suitable path for the current necessary change towards a transformative education for sustainable development goals (ESDGs), and further research on such direction is needed.

\section{Strengths, Limitations and Future Work}

The strength of this study lies in the effort to bridge contents and competences traditionally delivered independently in different courses in an interdisciplinary module, despite the current constraints of pre-service primary teachers' STEM-related curriculum content. To achieve this, a whole process of design and curricular integration of science, mathematics, and sustainability concepts and competences has been presented and can serve as a model for similar interventions. The topic of air quality has strong links with citizen-science initiatives that aim to raise public awareness about the negative impact of air pollution through the use of indicator plants or lichen monitoring [35]. Similar activities could be brought into our OLG in a straightforward manner and would constitute a research opportunity in a formal education setting.

Another strength is the use of both quantitative and qualitative methods of data analysis to determine knowledge change and perceived relevance of ESD. The pilot nature of the study implied that this intervention was assessed in a small cohort of students, which could risk uncertainty in statistical significance testing and may prevent generalizability. However, 15-20 individuals is the optimum size for delivering practical sessions both in the labs (including computing) and in the OLG. An increase in sample size in future implementations could be achieved by merging data from different lab groups or extending the research to multiple academic years. Likewise, segregation of the data by demographic variables, such as gender, was not feasible due to the limited sample size. Considering the role that gender-based approaches have on attitudes towards STEM topics and behavioral change related to sustainability [65], this is something that will merit further investigation in future implementations.

The use of the OLG proved to be a meaningful learning context from which to conclude air quality, weather parameter analysis, and environmental implications. A limitation of this pilot study was the time spent outdoors. In the future, we aim to allocate more hours to this. This would provide the opportunity to evaluate the use of OLG in a controlled experimental setting.

Supplementary Materials: The following are available online at https://www.mdpi.com/article/ $10.3390 / \mathrm{su1} 13084500 / \mathrm{s} 1$. Table S1. Scoring and frequency of results in the content knowledge questionnaire pre- and post-intervention. Table S2: Tasks from the self-efficacy scale about ESD and from the perceived relevance of ESD scale based on [50]. Table S3: Statistics of the scores in the preand post-implementation STEM knowledge questionnaires.

Author Contributions: Conceptualization, E.A.-B., A.R.-G., D.Z., I.P.-A., and A.R.; methodology, E.A.-B., A.R.-G., and A.R.; performing teaching experiments: E.A.-B. and A.R.-G.; data analysis, A.R., E.A.-B., and I.P.-A.; writing-original draft preparation, E.A.-B., A.R., and I.P.-A.; writing—review and editing, A.R., I.P.-A., A.R.-G., and D.Z.; project administration, A.R. and D.Z.; funding acquisition, A.R. and D.Z. All authors have read and agreed to the published version of the manuscript.

Funding: This research was funded by the Vice-Rectorate of Innovation, Social Commitment and Cultural Action (UPV/EHU), through the call for Projects of Educational Innovation, grant number PIE13-PIE-HECA-STEM and the call from the Directorate of Sustainability: Campus Bizia Lab 2018/19 edition, grant number 18ZUAZ. 
Institutional Review Board Statement: The study was conducted according to the guidelines of the Declaration of Helsinki, and approved by the Ethics Committee of UPV /EHU (Treatment code TI0123; 10/05/2019, more information here: http:/ /go.ehu.eus/C2TI0123, accessed on 17 April 2021).

Informed Consent Statement: Informed consent was obtained from all subjects involved in the study.

Data Availability Statement: The data presented in this study are available in the article or supplementary material.

Acknowledgments: We wish to thank R. Agerri and P. Rodriguez-Miñambres for the English editing and critical reading of the manuscript.

Conflicts of Interest: The authors declare no conflict of interest. The funders had no role in the design of the study; in the collection, analyses, or interpretation of data; in the writing of the manuscript, or in the decision to publish the results.

\section{References}

1. UNESCO. Education for Sustainable Development Goals: Learning Objectives; UNESCO Publishing: Pairs, French, 2017.

2. Leal Filho, W.; Levesque, V.R.; Salvia, A.L.; Paço, A.; Fritzen, B.; Frankenberger, F.; Damke, L.I.; Brandli, L.L.; Ávila, L.V.; Mifsud, M.; et al. University Teaching Staff and Sustainable Development: An Assessment of Competences. Sustain. Sci. 2020, 16, 101-116. [CrossRef]

3. United Nations. Transforming Our World: The 2030 Agenda for Sustainable Development; Division for Sustainable Development Goals: New York, NY, USA, 2015.

4. Granados Sanchez, J.; Wals, A.; Ferrer-Balas, D.; Waas, T.; Imaz, M.; Nortier, S.; Svanström, M.; Land, H.; Arriaga, G. Sustainability in Higher Education: Moving from Understanding to Action, Breaking Barriers for Transformation; GUNI: Barcelona, Spain, 2011; Volume 4, pp. 193-207. ISBN 978-0-230-53555-8.

5. Albareda-Tiana, S.; Vidal-Raméntol, S.; Pujol-Valls, M.; Fernández-Morilla, M. Holistic Approaches to Develop Sustainability and Research Competencies in Pre-Service Teacher Training. Sustainability 2018, 10, 3698. [CrossRef]

6. Rieckmann, M. Future-Oriented Higher Education: Which Key Competencies Should Be Fostered through University Teaching and Learning? Futures 2012, 44, 127-135. [CrossRef]

7. Risopoulos-Pichler, F.; Daghofer, F.; Steiner, G. Competences for Solving Complex Problems: A Cross-Sectional Survey on Higher Education for Sustainability Learning and Transdisciplinarity. Sustainability 2020, 12, 6016. [CrossRef]

8. Hernández-Barco, M.; Sánchez-Martín, J.; Blanco-Salas, J.; Ruiz-Téllez, T. Teaching Down to Earth-Service-Learning Methodology for Science Education and Sustainability at the University Level: A Practical Approach. Sustainability 2020, $12,542$. [CrossRef]

9. Sáez de Cámara, E.; Fernández, I.; Castillo-Eguskitza, N. A Holistic Approach to Integrate and Evaluate Sustainable Development in Higher Education. The Case Study of the University of the Basque Country. Sustainability 2021, 13, 392. [CrossRef]

10. Badea, L.; Șerban-Oprescu, G.L.; Dedu, S.; Piroșcă, G.I. The Impact of Education for Sustainable Development on Romanian Economics and Business Students' Behavior. Sustainability 2020, 12, 8169. [CrossRef]

11. Merrill, C.; Daugherty, J. The Future of TE Masters Degrees: STEM. In Proceedings of the International Technology Education Association, Louisville, KY, USA, 2009.

12. Doménech, J. STEM: Oportunidades y retos desde la Enseñanza de las Ciencias [STEM: Opportunities and challenges from Science Education]. Univ. Tarracon. Rev. Ciènc. Educ. 2019, 1, 154-168. [CrossRef]

13. Torres, M.P.; Couso, D.; Márquez, C. ¿Cómo diseñar un buen proyecto STEM? Identificación de tensiones en la co-construcción de una rúbrica para su mejora [How to design a good STEM project? Identification of tensions in the co-construction of a rubric for its improvement]. Rev. Eureka Sobre Enseñ. Divulg. Las Cienc. 2021, 18, 1301-1321. [CrossRef]

14. Adams, A.E.; Miller, B.G.; Saul, M.; Pegg, J. Supporting Elementary Pre-Service Teachers to Teach STEM through Place-Based Teaching and Learning Experiences. Electron. J. Sci. Educ. 2014, 18, 1-22.

15. Annan-Diab, F.; Molinari, C. Interdisciplinarity: Practical Approach to Advancing Education for Sustainability and for the Sustainable Development Goals. Int. J. Manag. Educ. 2017, 15, 73-83. [CrossRef]

16. Martins, A.A.; Mata, T.M.; Costa, C.A.V. Education for Sustainability: Challenges and Trends. Clean Technol. Environ. Policy 2006, 8, 31-37. [CrossRef]

17. Kelley, T.R.; Knowles, J.G. A Conceptual Framework for Integrated STEM Education. Int. J. STEM Educ. 2016, 3, 11. [CrossRef]

18. Del Cerro-Velázquez, F.; Lozano-Rivas, F. Education for Sustainable Development in STEM (Technical Drawing): Learning Approach and Method for SDG 11 in Classrooms. Sustainability 2020, 12, 2706. [CrossRef]

19. Yanez, G.A.; Thumlert, K.; de Castell, S.; Jenson, J. Pathways to Sustainable Futures: A “Production Pedagogy" Model for STEM Education. Futures 2019, 108, 27-36. [CrossRef]

20. Smith, C.; Watson, J. Does the Rise of STEM Education Mean the Demise of Sustainability Education? Aust. J. Environ. Educ. 2019, 35, 1-11. [CrossRef]

21. UNESCO. UNESCO Roadmap for Implementing the Global Action Programme on Education for Sustainable Development; UNESCO Digital Library: Paris, France, 2014; p. 38. 
22. Lozano, R.; Merrill, M.Y.; Sammalisto, K.; Ceulemans, K.; Lozano, F.J. Connecting Competences and Pedagogical Approaches for Sustainable Development in Higher Education: A Literature Review and Framework Proposal. Sustainability 2017, 9, 1889. [CrossRef]

23. Leicht, A.; Heiss, J.; Won, J. Issues and Trends in Education for Sustainable Development; UNESCO Publishing: Paris, France, 2018; ISBN 978-92-3-100244-1.

24. Murga-Menoyo, M.Á. Competencias para el desarrollo sostenible: Las capacidades, actitudes y valores meta de la educación en el marco de la Agenda global post-2015 [Competencies for sustainable development: the skills, attitudes and values of education within the framework of the post-2015 global Agenda]. Foro Educ. 2015, 13, 55-83. [CrossRef]

25. SDSN Australia/Pacific. Getting Started with the SDGs In Universities; Sustainable Development Solutions Network: Melbourne, Australia, 2017.

26. Vega-Marcote, P.; Varela-Losada, M.; Álvarez-Suárez, P. Evaluation of an Educational Model Based on the Development of Sustainable Competencies in Basic Teacher Training in Spain. Sustainability 2015, 7, 2603-2622. [CrossRef]

27. Santaolalla, E.; Urosa, B.; Martín, O.; Verde, A.; Díaz, T. Interdisciplinarity in Teacher Education: Evaluation of the Effectiveness of an Educational Innovation Project. Sustainability 2020, 12, 6748. [CrossRef]

28. Martins-Loução, M.A.; Gaio-Oliveira, G.; Barata, R.; Carvalho, N. Inquiry-Based science learning in the context of a continuing professional development programme for biology teachers. J. Biol. Educ. 2020, 54, 497-513. [CrossRef]

29. Sobel, D. Place-Based Education: Connecting Classrooms and Communities; Orion: Great Barrington, MA, USA, 2013; ISBN 978-1935713-05-0.

30. Semken, S.; Freeman, C.B. Sense of Place in the Practice and Assessment of Place-Based Science Teaching. Sci. Educ. 2008, 92, 1042-1057. [CrossRef]

31. Gozalbo, M.E.; Rey-Baltar, D.Z.; González, A.R. Huertos EcoDidácticos y Educación para la Sostenibilidad. Experiencias educativas para el desarrollo de competencias del profesorado en formación inicial [Organic Learning Gardens and Education for Sustainability. Educational experiences for the development of competencies of teachers in initial training]. Rev. Eureka Sobre Enseñ. Divulg. Las Cienc. 2018, 15, 1501. [CrossRef]

32. Pérez-López, R.; Eugenio-Gozalbo, M.; Zuazagoitia, D.; Ruiz-González, A. Organic Learning Gardens in Higher Education: Do They Improve Kindergarten Pre-Service Teachers' Connectedness to and Conception of Nature? Front. Psychol. 2020, 11, 282. [CrossRef] [PubMed]

33. Solé, C.; Gallego, È.T.; Couso, D. ¿Qué modelo de materia explica la contaminación?: Explorando el modelo corpuscular en la mesoescala [What model of matter explains pollution?: Exploring the corpuscular model in the mesoscale]. Alambique Didáctica Las Cienc. Exp. 2020, 101, 30-36.

34. Villavicencio, J.; Benitez, A.; Barlow, J.; Chowdhury, Z. Assessing Air Quality through a Sustainable Educational Model. J. Sustain. Educ. 2018, 19.

35. Agathokleous, E.; Saitanis, C.J.; Feng, Z.; De Marco, A.; Araminiene, V.; Domingos, M.; Sicard, P.; Paoletti, E. Ozone Biomonitoring: A Versatile Tool for Science, Education and Regulation. Curr. Opin. Environ. Sci. Health 2020, 18, 7-13. [CrossRef]

36. Celikler, D. Determining the knowledge level of pre-service elementary science teachers about air pollution. In Proceedings of the 3rd World Conference on Educational Sciences-2011, Bahcesehir University, Istanbul, Turkey, 3-7 February 2011; Akcamete, G., Uzunboylu, H., Oulmu, S., Karahoca, A., Babadoan, C., Ozdamli, F., Kanbul, S., Eds.; Elsevier Science Bv: Amsterdam, The Netherlands, 2011; Volume 15, pp. 1445-1456.

37. Wahlström, M.; Kocyba, P.; de Vydt, M.; De Moor, J. Protest for a Future: Composition, Mobilization and Motives of the Participants in Fridays for Future Climate Protests on 15 March, 2019 in 13 European Cities; Protest for a Future: Bath, UK, 2019.

38. Sterling, S. Contradiction or complement: Can higher education be deeper education? In Intergenerational Learning and Transformative Leadership for Sustainable Futures; Wageningen Academic Publishers: Wageningen, The Netherlands, 2014; pp. 139-152. ISBN 978-90-8686-252-8.

39. Freeman, S.; Eddy, S.L.; McDonough, M.; Smith, M.K.; Okoroafor, N.; Jordt, H.; Wenderoth, M.P. Active Learning Increases Student Performance in Science, Engineering, and Mathematics. Proc. Natl. Acad. Sci. USA 2014, 111, 8410-8415. [CrossRef]

40. Schmidt, M.; Fulton, L. Transforming a Traditional Inquiry-Based Science Unit into a STEM Unit for Elementary Pre-Service Teachers: A View from the Trenches. J. Sci. Educ. Technol. 2016, 25, 302-315. [CrossRef]

41. Psillos, D.; Kariotoglou, P. Theoretical Issues Related to Designing and Developing Teaching-Learning Sequences. In Iterative Design of Teaching-Learning Sequences: Introducing the Science of Materials in European Schools; Psillos, D., Kariotoglou, P., Eds.; Springer: Dordrecht, The Netherlands, 2016; pp. 11-34. ISBN 978-94-007-7808-5.

42. Ministerio de Educación, Cultura y Deporte. Informe de Verificación del Grado de Educación Primaria de la Universidad del País Vasco (UPV/EHU) [Verification Report of the Degree in Primary Education of the University of the Basque Country (UPV/EHU)]; Gobierno de España: Madrid, Spain, 2014.

43. Granados Sánchez, J.; Junyent i Pubill, M. Retos y oportunidades en la ambientalización curricular [Challenges and opportunities in curriculum environmentalization]. Cuad. Pedagog. 2015, 460, 48-52.

44. Guisasola, J.; Zuza, K.; Ametller, J.; Gutierrez-Berraondo, J. Evaluating and Redesigning Teaching Learning Sequences at the Introductory Physics Level. Phys. Rev. Phys. Educ. Res. 2017, 13, 020139. [CrossRef]

45. Johnson, C.C.; Peters-Burton, E.E.; Moore, T.J. STEM Road Map: A Framework for Integrated STEM Education; Routledge: London, UK, 2015; ISBN 978-1-317-62019-8. 
46. Smith, C.; Fitzallen, N.; Watson, J.; Wright, S. The Practice of Statistics for STEM: Primary Students and Pre-Service Primary Teachers Exploring Variation in Seed Dispersal. Teach. Sci. 2019, 65, 38-47.

47. Marshall, J.C.; Smart, J.B.; Alston, D.M. Inquiry-Based Instruction: A Possible Solution to Improving Student Learning of Both Science Concepts and Scientific Practices. Int. J. Sci. Math. Educ. 2017, 15, 777-796. [CrossRef]

48. Council, N.R. Inquiry and the National Science Education Standards: A Guide for Teaching and Learning; National Academies Press: Columbia, WA, USA, 2000; ISBN 978-0-309-06476-7.

49. Keeley, P.D.; Tucker, L. Are they talking about Climate or Weather? In Uncovering Student Ideas in Earth and Environmental Science. 32 New Formative Assessment Probes; NSTA Press: Arlington, VI, USA, 2016; pp. 73-76. ISBN 978-1-938946-47-9.

50. Tomas, L.; Girgenti, S.; Jackson, C. Pre-Service Teachers' Attitudes toward Education for Sustainability and Its Relevance to Their Learning: Implications for Pedagogical Practice. Environ. Educ. Res. 2017, 23, 324-347. [CrossRef]

51. Barnard, A.; McCosker, H.; Gerber, R. Phenomenography: A Qualitative Research Approach for Exploring Understanding in Health Care. Qual. Health Res. 1999, 9, 212-226. [CrossRef] [PubMed]

52. Elsasser, S.W.; Dunlap, R.E. Leading Voices in the Denier Choir: Conservative Columnists' Dismissal of Global Warming and Denigration of Climate Science. Am. Behav. Sci. 2013, 57, 754-776. [CrossRef]

53. Myers, G.; Boyes, E.; Stanisstreet, M. School Students' Ideas about Air Pollution: Knowledge and Attitudes. Res. Sci. Technol. Educ. 2004, 22, 133-152. [CrossRef]

54. Kilinc, A.; Stanisstreet, M.; Boyes, E. Turkish Students' Ideas about Global Warming. Int. J. Environ. Sci. Educ. 2008, 3, 89-98.

55. Choi, S.; Niyogi, D.; Shepardson, D.P.; Charusombat, U. Do Earth and Environmental Science Textbooks Promote Middle and High School Students' Conceptual Development About Climate Change? Textbooks' Consideration of Students' Misconceptions. Bull. Am. Meteorol. Soc. 2010, 91, 889-898. [CrossRef]

56. Pozo, J.I. Las Ideas del Alumnado Sobre la Ciencia: De Dónde Vienen, a Dónde van ... y Mientras Tanto qué Hacemos con Ellas [Students' Ideas about Science: Where They Come from, Where They Go... and in the Meantime What We Do with Them]; Grao: Barcelona, Spain, 1996.

57. Keeley, P. Uncovering Student Ideas in Life Science; NSTA Press: Arlington, WA, USA, 2011; ISBN 978-1-936137-51-0.

58. Henriques, L. Children's Ideas About Weather: A Review of the Literature. Sch. Sci. Math. 2002, 102, 202-215. [CrossRef]

59. Chang, C.-H.; Pascua, L. Singapore Students' Misconceptions of Climate Change. Int. Res. Geogr. Environ. Educ. 2016, 25, 84-96. [CrossRef]

60. Toulmin, S.E. The Uses of Argument, 2nd ed.; Cambridge University Press: Cambridge, UK, 2003; ISBN 978-0-521-82748-5.

61. Sakai, K.; Higashinaka, R.; Yoshikawa, Y.; Ishiguro, H.; Tomita, J. Hierarchical Argumentation Structure for Persuasive Argumentative Dialogue Generation. IEICE Trans. Inf. Syst. 2020, 103, 424-434. [CrossRef]

62. Levinson, R. Science Education and Democratic Participation: An Uneasy Congruence? Stud. Sci. Educ. 2010, 46, 69-119. [CrossRef]

63. Bonnett, M. Education for Sustainability as a Frame of Mind. Environ. Educ. Res. 2002, 8, 9-20. [CrossRef]

64. Burbules, N.C.; Fan, G.; Repp, P. Five Trends of Education and Technology in a Sustainable Future. Geogr. Sustain. 2020, 1, 93-97. [CrossRef]

65. Benavent, X.; de Ves, E.; Forte, A.; Botella-Mascarell, C.; López-Iñesta, E.; Rueda, S.; Roger, S.; Perez, J.; Portalés, C.; Dura, E.; et al. Girls4STEM: Gender Diversity in STEM for a Sustainable Future. Sustainability 2020, 12, 6051. [CrossRef] 